\title{
Do Professional Commitment and Anticipatory Socialization Affect The Intention To Do Whistleblowing?
}

\author{
Claudia Tompunu ${ }^{1}$, Frisky Jeremy Kasingku², Ika Prayanthi ${ }^{2}$ \\ 1. PT Triputra Energi Megatara, Menara Kadin Indonesia Lt. 20, Jl. H. R. Rasuna Said Kav. 2\&3, Setia Budi, Jakarta, 12950 \\ 2. Departement of Economics and Business, Universitas Klabat, Jl. Arnold Mononutu, Airmadidi Bawah, Kec. Airmadidi, Kabupaten Minahasa Utara,
} Sulawesi Utara 95371

\begin{tabular}{l|c}
\hline ARTICLE INFO & ABSTRACT \\
\hline
\end{tabular}

Keywords:

Anticipatory socialization, Professional commitment, Whistleblowing

Kata Kunci:

Sosialisasi antisipatif Komitmen profesional, Pelaporan pelanggaran
Corresponding author: frisky.kasingku@unklab.ac.id
The corruption in Indonesia is one of the biggest problems the government and the business must face. Employee in the entity may provide one of the solutions for this problem. They may do the whistleblowing when they know that there is violation in the entity. Professional commitment and anticipatory socialization are the factors to foster whistleblowing. This study aims to obtain empirical evidence regarding the impact of professional commitment and anticipatory socialization toward whistleblowing intention. 155 eligible accounting students are taken as subjects for this study. The questionnaire is disseminated electronically to the sample. As a result, professional commitment affects whistleblowing intentions of accounting students. Furthermore, male who profess professional commitment will likely do the action of whistleblowing compare to female. On the other hand, there is no statistical evidence found to prove that anticipatory socialization affects the intention to do whistleblowing. Consequently, the system of the company must facilitate the improvement of professional commitment so it may foster the intention of the employees to whistleblow. Therefore, manager should pay attention to degree of the professional commitment of the employees.

\section{SARI PATI}

Korupsi di Indonesia adalah salah satu masalah terbesar yang harus dihadapi pemerintah dan pebisnis. Karyawan di dalam organisasi dapat menjadi salah satu solusi untuk masalah ini. Mereka dapat melakukan whistleblowing ketika mereka tahu bahwa ada pelanggaran dalam organisasi. Komitmen profesional dan sosialisasi antisipatif adalah faktor-faktor untuk meningkatkan niat untuk melakukan whistleblowing. Penelitian ini bertujuan untuk mendapatkan bukti empiris mengenai dampak komitmen profesional dan sosialisasi antisipatif terhadap niat melakukan whistleblowing. 155 mahasiswa akuntansi yang memenuhi syarat diambil sebagai subjek untuk penelitian ini. Kuesioner disebar secara elektronik ke sampel. Hasilnya, komitmen profesional memengaruhi niat whistleblowing. Lebih lanjut lagi, pria yang memiliki komitmen profesional lebih cenderung melakukan tindakan whistleblowing dibanding wanita. Disisi lain, tidak ditemukan bukti bahwa sosialisasi antisipatif memengaruhi niat untuk melakukan whistleblowing. Implikasinya, sistem perusahan perlu memfasilitasi peningkatan komitmen profesional agar menumbuhkan niat dari karyawan untuk melakukan whistleblowing. Manajer perlu memperhatikan tingkat komitmen profesional dari karyawan. 


\section{INTRODUCTION}

Along with the growing economy in the world, the frequency of accounting fraud cases that occurs within a company or a government agency is also increasing. In 2014, the Association of Certified Fraud Examiners issued a Global Study on Occupational Fraud and Abuse, in which the report contains a number of accounting fraud cases that occurred in several countries including 646 cases which occurred in the United States, 173 cases in Africa, 129 in the Asia Pacific, 55 cases in South Asia (Association of Certified Fraud Examiners, 2014). While for the 2016 report, there were 1038 fraud cases occurring in the United States, 285 cases in Africa, 221 cases in the Asia Pacific region, 98 cases in South Asia (Association of Certified Fraud Examiners, 2016). It shows that there is an increase in accounting fraud cases in several countries around the world every year.

One example of the fraudulent practices which is found in Indonesia is corruption cases. Corruption Perceptions Index-Transparency International (2017) released a corruption perception index of countries in the world for 2017. They use a scale of 0-100 for the score achievement for each country. The more the entity reach zero scale, the more corrupt the entity is. Indonesia reach $96^{\text {th }}$ out of 180 countries by having the score of 37 . The ranking indicates that Indonesia's perception index decreases compare to the achievement from 2016 (ranking 90 out of 180) By having a downgrade in 2017, it means that there is an increase in corruption violation cases in Indonesia. It proves that corruption violation cases have become part of Indonesia for decades (Prabowo \& Cooper, 2016). According to Fagbemi (2017), unethical practices such as accounting fraud and corruption have become one of the biggest problems that must be faced by every entity. Based on that theory, Miceli and Near (2005) state that the most effective stakeholders to reduce the occurrence of unethical behaviors are the member of the organization itself. It means that employees play an important role in the prevention of fraud in an entity. Reporting on unethical actions by someone within the company to a party who can take action on the violation is known as whistleblowing (Miceli \& Near, 1985).

According to Tadu and Mukonya (2016), being a whistleblower is not easy, therefore, some people will not dare to inform fraud or deception occurring within their organization to the company management. According to Jalilvand (2017), a whistleblower has the potential to be threatened with job layoff or experiencing various other forms of retaliation. Since there is still the potential risk of retaliation, then it can affect one's intention to take the decision to do the whistleblowing. Consequently, it takes courage and determination for someone to do whistleblowing.

Several previous studies have tried to find out what influences one's intention to do whistleblowing, among them is the strong commitment of someone to his profession which can become the reason for him or her to do whistleblowing. In a study conducted by Kaplan and Whitecotton (2001), they found a positive influence between professional commitment and the intention of an auditor to perform whistleblowing. Those results are supported by a study conducted by Elias (2008) where professional commitment affected the intention of auditing students to do whistleblowing. However, different results are shown in the study of Siallagan, Rohman, Januarti, and Din (2017), there is no significant effect between professional commitment and one's intention to do whistleblowing.

In addition to professional commitments, there are other factors that can influence one's intention to do whistleblowing, which is anticipatory socialization. In a study conducted by Elias (2008), he found that one's anticipatory socialization influences his intention to do whistleblowing. However, it is different from the results obtained by Jalil (2014), in which the anticipatory socialization does not influence one's intention to do whistleblowing. Furthermore, there are also gender differences that can influence someone in terms of decision 
making, orientation, and evaluation which require moral and ethical considerations (Loo, 2002). According to Ahmad, Smith, and Ismail (2012), their study found that women and men tend to be different in terms of ethics and behaviors. Based on the differences in the behavior, some researchers conducted studies related to the intention to do whistleblowing seen from the gender factor. The result is that male accountants tend to do the act of whistleblowing compared to female accountants (Liyanarachchi \& Adler, 2011). However, it is different from the study results of Seifert, Sweeney, Joireman, and Thornton (2010) who found out that women tend to do whistleblowing than men. By still having inconsistency results of previous studies, this research aims to re-examine the phenomena, whether professional commitment and socialization anticipatory may influence the intention of individuals to do whistleblowing or not.

According to Davis (1996), there are two theories in whistleblowing which are standard theory and complicity theory. The standard theory states that when analyzing a case, a whistleblower must take into himself before he reveals the error to the public. While the complicity theory is when someone is morally obliged to reveal what he knows to the public.

Whistleblowing is a system of information disclosure about an action that is considered to contain a violation of the law such as corruption and unethical behavior and fraud by an employee within a company (Vinten, 2000). Perks and Smith (2008) state that whistleblowing occurs when an employee found an error in his organization, and then report it to the public or authorities. According to the National Committee on Indonesian Governance Policy in the book of Whistleblowing Reporting Guidelines (2008), it states that a person who reports a violation or act of fraud is called whistleblower. As for the reason an employee becomes a whistleblower is when he feels that there is an error or fraud that may harm the organization, its employees, as well as the outside community (Jalilvand, Vosta \& Yasini, 2017).

\section{Professional Commitment}

Professional commitment is a form of responsibility, a sense of awareness, and an attitude to defend the values contained in a profession, making an individual capable of forming a strong commitment (Elias, 2008). Garman (2006) defines professional commitment as an effort to align the personal attitude and the organization with the ethical standards which cover the responsibility to the community. The same thing is stated by Ahmad, Anantharaman, and Ismail (2012) that professional commitment not only determines one's loyalty to the profession but also adherence to the code of professional ethics.

Aranya and Ferris (1998) describe the characteristics of professional commitment: first, the identification of which consists of acceptance of goals, the similarity of personal values with the profession, as well as the pride of being part of the profession. Second, involvement is the availability of someone to work and do his best for the profession. Third, loyalty is an emotional bond as well as a desire to remain as part of the member.

To become a professional, an accountant is expected to behave ethically in every work that is done. The ethical behavior of a professional accountant is very important in determining the status and credibility of the profession in the field of accounting (Chan and Leung, 2006). According to Siallagan, et al (2017) a number of fraud cases that occur both in the government and organizations reflect the low professionalism of the members or employees.

Research conducted by Elias (2008) found that professional commitment significantly influences the intention of auditing students to do whistleblowing. This result is supported by the findings of Mela, Fito, Zarefar, and Andrew (2015) where there is a significant difference between professional commitment and the intention of auditing students to do whistleblowing. Meanwhile, Kaplan and Whitecotton (2001) conducted a study 
of accountants found that the higher the level of professional accountants, the greater the tendency to do whistleblowing.

However, different results are shown in a study conducted by Yetmar and Eastman (2000) where professional commitment does not influence the intention of accountants to do whistleblowing. The results are in line with a study from Siallagan, Rohman, Januarti and Din (2017) who found no significant influence of one's professional commitment with the intention of accountants to do whistleblowing.

\section{H1: Professional commitment significantly influences the intention of individual to do whistleblowing.}

According to Elias (2008) anticipatory socialization is the formation of beliefs and attitudes adopted by a particular group as their preparation to become a part of the particular group. Meanwhile, Merton and Rossi (1968) define anticipatory socialization as the adoption process of one's attitudes and beliefs of a particular group or culture before he becomes a member of the particular group. Garavan and Morley (1997) suggest that anticipatory socialization is the result of all the learning that one gets before entering the world of work.

According to Weight (1997), anticipatory socialization has long term effects because the adoption process begins from the environment of family, community, and school. According to Sang, Ison, Dainty, and Powell (2009), the process of anticipatory socialization can make someone has an expectation in the career that he owns, because an individual anticipates attitudes, norms, and values of the profession during the socialization process. Misperception can occur in the profession if the individual fails to adopt the values of the profession in the process of knowledge transfer (Mela et al, 2016). Anticipatory socialization process on students begins when they learn to prioritize the needs of users of financial statements (Mela et al, 2016). According to Clikemen and Henning (2000), there are four factors that serve as the basis for measuring the students' perceptions of the importance of accounting financial statements including the first is misstatements, disclosure of sensitive information, disclosure of costs and profits of a company, responsibility.

Elias (2008) concludes that the higher the level of anticipatory socialization, the higher one's tendency to do whistleblowing. However, different results are shown in a study by Jalil (2014) in which anticipatory socialization does not influence one's actions to do whistleblowing. The same thing happened with the results obtained by Mela et al (2016) where there is no significant influence between anticipatory socialization and the intention of auditing students to do whistleblowing.

$\mathrm{H} 2$ : Anticipatory socialization significantly influences the intention of accounting students to do whistleblowing.

H3: Professional commitment and anticipatory socialization simultaneously have a significant effect on the intention of accounting students to do whistleblowing.

\section{METHODS}

This study uses a quantitative approach with causal descriptive method. The population of this study is all students of the Accounting Department of the Faculty of Economics and Business at University of Klabat. Accounting students are selected as the population because they are the candidates for future accountants and auditors that are likely to face numerous fraud cases in their companies (Kennett, et al., 2011). Accounting students who have taken or are taking auditing class are the sample of this study. The primary data are obtained from the results of questionnaires which are distributed or disseminated, either directly or electronically to 155 respondents. The questionnaire used is an adoption of a study by Mela et al (2016). The independent variables are professional commitment and anticipatory socialization, while 
the dependent variable is the intention of the accounting students to do whistleblowing and the gender as the control variable.

\section{RESULTS AND DISCUSSION}

Table 1 shows each of independent variables have tolerance value $>0.1$ and $\mathrm{VIF}$ value $<10$. Therefore it can be concluded that there is no multicollinearity between independent variables in this study.

H1: Professional commitment significantly influences the intention of accounting students to do whistleblowing.

The results of the regression calculation in Table 2 show the significant value of .032 for the professional commitment variable, which means that $p$-value $\leq$ .05 . Therefore, it can be concluded that if it is partially tested, professional commitment significantly influences the intention of the accounting students to do whistleblowing, thus $\mathrm{H} 1$ is supported.
This hypothesis test result is consistent with prior research by Elias (2008) who found out that professional commitment significantly influences the intention of auditing students to do whistleblowing. This result is also supported by a study by Mela et al (2016) who found out that professional commitment significantly influences one's actions to do whistleblowing.

According to Elias (2008) accounting students who have higher commitment assume that fraud actions on financial statements are a form of violation of ethics so that they would be reluctant to commit fraud actions. Ahmad, Anantharaman, and Ismail (2012) state that in addition to loyalty to profession, professional commitment also determine one's adherence to the professional code of ethics. Jalil (2014) adds that if someone is committed to his profession, he will not engage in actions that are contrary to the norms and ethics that exist in the profession.

Tabel 1. The Results of Multicollinearity Test

\begin{tabular}{|c|c|c|}
\hline Variable & Collinearity Tolerance & Statistics VIF \\
\hline Professional commitment & .980 & 1.021 \\
\hline Anticipatory socialization & .977 & 1.023 \\
\hline Gender & .997 & 1.003 \\
\hline
\end{tabular}

Source: SPSS data

Tabel 2. The Results of Hypotesis Test Partially

\begin{tabular}{lcc}
\hline Variable & Unstandardized Coefficients & Significancy \\
& Beta & \\
\hline Professional commitment & .117 & .032 \\
Anticipatory socialization & -.006 & .944 \\
\hline
\end{tabular}

Source: SPSS data

Tabel 3. The Results of Hypotesis Test Partially for Gender Variable

\begin{tabular}{llcl}
\hline Gender & & Unstandardized Coefficient Beta & Sig \\
\hline \multirow{2}{*}{ Female } & Professional commitment & .036 & .555 \\
& Anticipatory socialization & .004 & .969 \\
\multirow{2}{*}{ Male } & Professional commitment & .254 & .014 \\
& Anticipatory socialization & -.038 & .815 \\
\hline
\end{tabular}

Source: SPSS data 
Table 3 shows the influence of professional commitment to the intention to do whistleblowing when seen by gender that is male and female. The table explains the male has significant value of 0.014 . Therefore, it can be concluded that male who profess professional commitment will likely to do whistleblowing. These hypothesis testing results are consistent with the previous studies of Liyanarachchi and Adler (2011) who found out that men are more likely to commit the action of whistleblowing than women.

Marsden, Kalleberg, and Cook (1993) suggest that men tend to have a greater level of commitment than women in their professions. In addition, the results of this study support the view that is expressed by Breesch and Branson (2009) which states that men are more daring in terms of taking risks than women. Men are more concerned with justice, rules, and individual rights in solving moral problems than women (Wijayanti, Kasingku \& Rukmana, 2017).

$\mathrm{H} 2$ : Anticipatory socialization significantly influences the intention of accounting students to do whistleblowing.

The results of regression calculation in Table 2 show the significant value of .944 for the variable of anticipatory socialization, which means that the p-value $\geq .05$ or $.944 \geq .05$, then it can be concluded that if it is partially tested, socialization anticipatory does not significantly influence the intention of the accounting students to do whistleblowing, thus $\mathrm{H} 2$ is not supported.

This hypothesis test result is consistent with prior research by Jalil (2014) who found that anticipatory socialization does not significantly influence one's intention to do whistleblowing. The study is supported by Mela et al (2016) who found that anticipatory socialization does not significantly influence one's actions to do whistleblowing.

According to Garavan and Morley (1997), anticipatory socialization is the result of one's learning before he entered the world of work. Anticipatory socialization occurs when someone adopts an attitude and belief through education, as one of the ways. In accordance with a study by Jalil (2014) which states that anticipatory socialization does not influence the action of whistleblowing, because the adoption of attitudes and beliefs are considered not able to be fully absorbed by the respondents. So that it is expected for the accounting lecturers to further increase the awareness of the students on the ethical problems that exist (Elias, 2008).

Tabel 4. The Results of Hypotesis Test Simultaneously

\begin{tabular}{ll}
\hline Item & Result \\
\hline Observation & 155 \\
Adj. $R^{2}$ & .013 \\
F-Value & 1.698 \\
Prob $(F)$ & .170 \\
\hline
\end{tabular}

Source: SPSS data

H3: Professional commitment and anticipatory socialization simultaneously have a significant effect on the intention of accounting students to do whistleblowing.

It can be seen in the significant value of .170 which is greater than .05. Hence, it can be concluded that the H3 is not supported, which means that professional commitment and anticipatory socialization do not simultaneously have a significant effect on the intention of the accounting students to do whistleblowing. This result supports a previous study conducted by Mela, et al. (2016) who found that professional commitment and anticipatory socialization have no relationship with the intention of students to do whistleblowing.

On the other hand, it can also be seen in Table 4 that the value of Adjusted $\mathrm{R}^{2}$ equals to .013 or $1.3 \%$ states that the variables of professional commitment and anticipatory socialization have contributed $1.3 \%$ to the intention of the accounting students to do whistleblowing and the remaining $98.7 \%$ is 
influenced by other variables that are not described in this study.

\section{MANAGERIAL IMPLICATION}

Managers can reap some benefits from the result of this study. Firstly, they can implement system to boost the motivation of the employee to do whistleblowing. Next, they can enchance the professional commitment of the employee for the employee to be more committed to their job so that they may report when there's any deviation done in their committed job environment. Lastly, the managers can create a safe system for the whistleblower to enchance the rate of whistleblowing. Furthermore, the implications of this study are that it is expected for the lecturers to emphasize the importance of ethical values, morals, integrity of the profession of accountants to the students who are the candidates for future accountants. The curriculum of accounting study can also be enhanced by adding some business ethics courses with real life cases.

\section{CONCLUSION}

From the results of the study that have been previously described, then we can conclude several things that, partially, professional commitment significant influences the intention of the accounting students to do whistleblowing which means that professional commitment becomes one of the supporting factors for students to report unethical acts committed by employees in the world of work later on. Meanwhile, the anticipatory socialization does not significantly influence the intention of the accounting students to do whistleblowing. By analyzing based on gender, men who have professional commitment are the ones who have the intention to do whistleblowing compared to women. As for the variable of anticipatory socialization of both men and women, both of them do not significantly influence the intention of doing whistleblowing. The results of multiple regression analysis concluded that professional commitment and anticipatory socialization do not simultaneously have a significant effect on the intentions of accounting students to do whistleblowing.

This study only took accounting students as the objects of the study and only limited on the variables of professional commitment, anticipatory socialization, and gender. Subsequent research can take different respondents such as employees of a company. Moreover, it can add other variables like retaliation, experiences, level of spiritual, and other demographic factors.

REFERENCES

International Research Journal of Business Studies (IRJBS)

Vol.x, No.x, Month 201x, pp. xx $\sim \mathrm{xx}$

ISSN: 2089-6271 | E-ISSN: 2338-4565 |www.irjbs.com

Association of Certified Fraud Examiners. (2014). Diunduh Oktober 15, 2018, from https://www.acfe.com/report-to-thenations/2018/\#download

Association of Certified Fraud Examiners. (2016). Diunduh 15 Oktober, 2018, from http://www.acfe.com/rttn2016/resources/ downloads.aspx 
Ahmad, S. A., Smith, M., \& Ismail, Z. (2012). Internal Whistle-Blowing Intentions: A Study of Demographic and Individual Factors. Journal of Modern Accounting and Auditing, 8(11), 1632-1645.

Breesch, D., \& Branson, J. (2009). The Effects of Auditor Gender on Audit Quality. The Ifcai University Press.

Corruption Perceptions Index. (2018, Februari 21). Diunduh Oktober 15, 2018, from Transparency International: https://www. transparency.org/news/feature/corruption_perceptions_index_2017

Clikeman, P. M., \& Henning, S. L. (2000). The Socialization of Undergraduate Accounting Students. Issues in Accounting Education, 15(1), 1-17.

Elias, R. (2008). Auditing Students' Professional Commitment and Anticipatory Socialization and Their Relationship to Whistleblowing. Managerial Auditing Journal, 23(3), 283-294.

Davis, M. (1996). Some Paradox of Whistleblowing. Business and Professional Ethics Journal, 15(1), 3-19.

Dworkin, T. M., \& Baucus, M. S. (1998). Internal vs. External Whistleblowers: A Comparison of Whistleblowering Processes. Journal of Business Ethics, 17(12), 1281-1298.

Fagbemi, T. O. (2017). Whistleblowing Intention: Evidence From Future Accountans in Universities Located in Kwara State, Nigeria. Osogbo Journal of Management, 2(1), 47-56

Garavan, T. N., \& Morley, M. (1997). The Socialization of High-Potential Graduates into the Organizations: Initial Expectations, Experiences and Outcomes. Journal of Managerial Psychology, 12(2), 118-137.

Ghozali, I. (2013). Aplikasi Analisis Multivariate dengan Program SPSS Cetakan VII. Semarang: Badan Penerbit Universitas Diponegoro.

Jalil, F. Y. (2014). Pengaruh Komitmen Profesional dan Sosialisasi Antisipatif Mahasiswa Audit terhadap Perilaku Whistleblowing. Jurnal Bisnis dan Manajemen, 4(2), 198-209.

Jalilvand, M. R., Vosta, S. N., \& Yasini, A. (2017). Motivational Antecedents of Whistleblowing in Iranian Public Service Organizations. Iranian Journal of Management Studies, 10(2), 385-408.

Kaplan, S. E., \& Whitecotton, S. M. (2001). An Examination of Auditor's Reporting Intentions When Another Auditor is Offered Client Employment. A Journal of Practice \& Theory, 20(1), 45-63.

Kennett, D., Downs, A., \& Durler, M. G. (2011). Accounting Student's Intent to Blow the Whistle on Corporate Fraudelent Financial Reporting: An Experiment. International Journal of Business and Social Science, 2(14), 14-23.

Liyanarachchi, G., \& Adler, R. (2011). Accountants' Whistle-Blowing Intentions: The Impact of. Australian Accounting Review, 21(2), 167-182.

Loo, R. (2002). The Distribution of Learning Styles and Types For Hard and Soft Business. Educational Psychology, 22(3), 349360 .

Prabowo, H. Y., \& Cooper, K. (2016). Re-Understanding Corruption in the Indonesian Public Sector Through Three Behavioral Lenses. Journal of Financial Crime, 23(4), 1028-1062.

Marsden, P. V., Kalleberg, A. L., \& Cook, C. R. (1993). Gender Differences in Organizational Commitment. Work and Occupations, 20(3), 368-390.

Mela, N. F., Zarefar, A., \& Andreas. (2016). The Relationship of Profesional Commitment of Auditing Student and Anticipatory Socialization toward Whistleblowing Intention. In 3rd Global Conference on Business and Social Science, 219, 507-512

Merton, R. K., \& Rossi, A. K. (1968). Contribution to the Theory of References Group Behavior. New York: The Free Press.

Miceli, M. P., \& Near, J. P. (2005). Standing Up or Standing by: What Predicts Blowing the Whistle on Organizational Wrongdoing? Research in Personnel and Human Resources Management, 24, 95-136.

Miceli, M. P., \& Near, J. P. (1985). Organizational Dissidence: The Case of Whistleblowing. Journal of Business Ethics, 4(1), 1-16.

Neufeldt, V. (1984). Webster's New World Dictionary. New York: Webster's New World Clevenland.

Tadu, R., \& Mukonya, S. (2016). Challenges of Whistle Blowing as a Corporate Governance Control Tool in the Zimbabwean Banking Sector During 2000-2008. Journal of Research in Business, Economics and Management, 6(3), $954-963$.

Santrock, J.W. (2009). Psikologi Pendidikan (3rd ed.). Jakarta: Salemba Humanika

Siallagan, H., Rohman, A., \& Din, M. (2017). The Effect of Professional Commitment, Attitude, Subjective Norms and Perceived Behavior Control on Whistle Blowing Intention. International Journal of Civil Engineering and Technology, 8(8), 508-519.

Vinten, G. (2000). Whistleblowing Towards Disaster Prevention and Management. Disaster Prevention and Management, 9(1), $18-28$.

Weight, W. (1977). An Empirical Study of the Professional Socialization of Accounting Students. International Journal of Accounting, 12(1), 55-77.

Wijayanti, D. M., Kasingku, F. J., \& Rukmana, R. (2017). Dilema Etika pada Akuntan - Sebuah Studi Persepsi Mahasiswa Akuntansi. Jurnal Dinamika Akuntansi dan Bisnis, 4(2), 159-172.

Yetmar, S. A., \& Eastman, K. K. (2000). Tax Practitioners' Ethical Sensitivity: A Model and Empirical Examination. Journal of Business Ethics, 26, 271-288. 